فراوانى آللى و زنوتيبى يلى مورفيسم rs2288258در ناحيه زنى HEXA در جمعيت اصفهان

نسرين وهاب'، على جزايرى'، صادق وليان بروجنى'"

ا) كروه زيستشناسى، دلنشكده علوم، دلنشاه (صنهان، (صفهان، ايرانغ

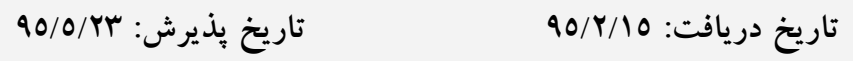

مقدمه: تاى ساكس يك بيمارى زنتيكى با توارث اتوزومى مغلوب است كه سيستم عصبى مركزى را دركير مى كند. ابيمارى به طور

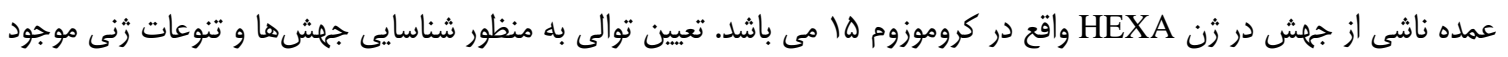

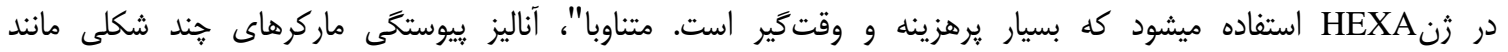

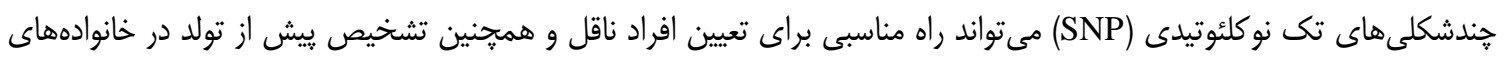
داراى فرزند مبتلا ارائه نمايد.

مواد و روث ها: در يايخاههاى داده موجود تعداد زيادى از ماركرهاى SNP براى ناحيه زنى HEXA معايل

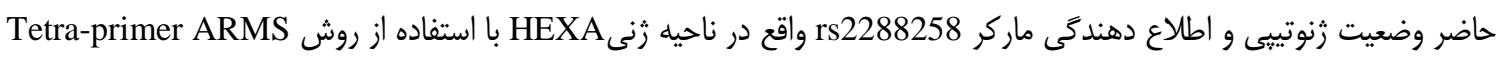

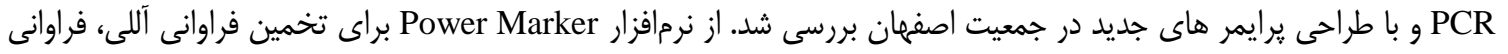

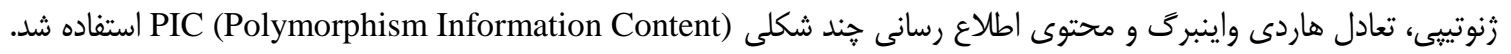

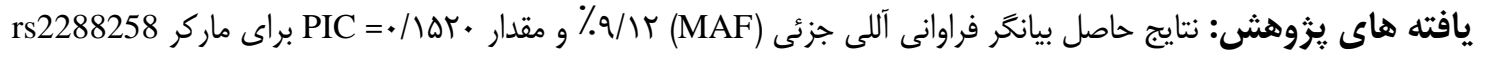

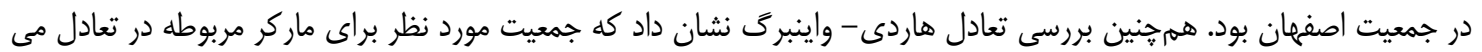

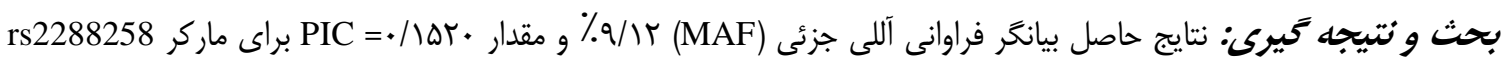

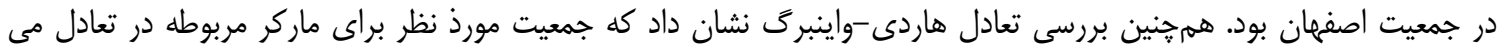

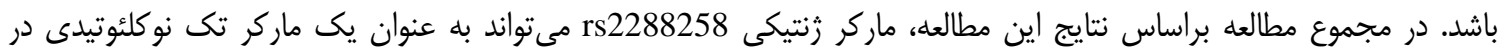

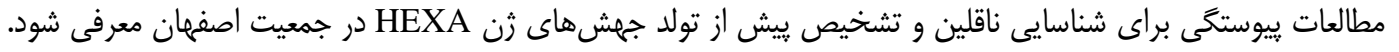

\footnotetext{
وازخكان كليدى: HEXA، آناليز ييوستخى، קند شكلى تك نوكلئوتيدى، جمعيت اصفهان
} 
كزارش شده است كه بعضى از آنها با HEXA مقدمه كروههاى نزادى خاص مرتبط هستند جهش شايع در

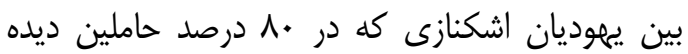

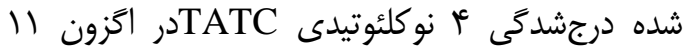
ثن HEXA است، اين جهش در بين غير يهوديان نيز

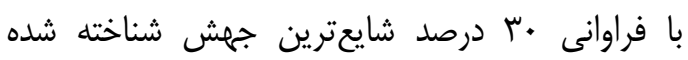
است(عاوVIV). جهش شايع در جمعيت كانادايىهاى فرانسوى تبار حذف V/9 كيلو بازى شامل كل اتزون 1

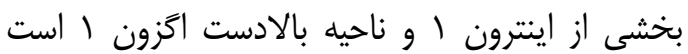

Amos Frisch زنتيكى جهش رايج بين يهوديان اشكنازى D15S981- اريكازئ (insTATCIrVA) D15S131- D15S1050- D15S197- D15S188

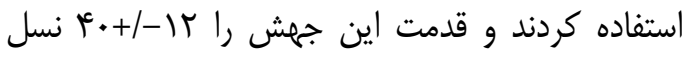

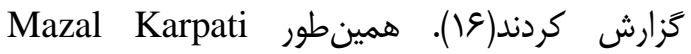
تاريخجه زنتيكى دو جهش جديد C1351G و

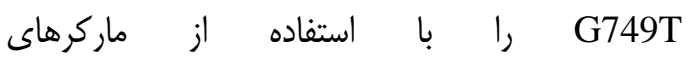
D15S131,D15S1025, D15S981, D15S1050

در جمعيت يهوديان عراقى بررسى كرد (19). در حال حاضر راهبرد اساسى براى مقابله با اين بيمارى برى

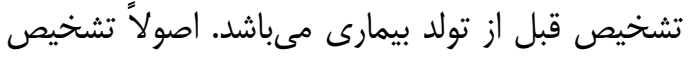
مولكولى تاى ساكس بر پايیه دو روش بررسى مستقيم جهشهاى زنى و بررسى غيرمستقيم توسط آناليز

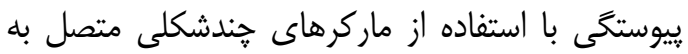

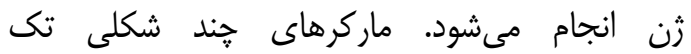

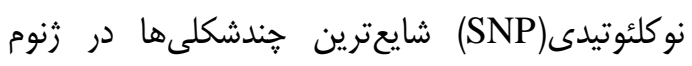

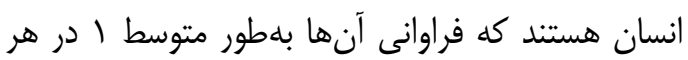

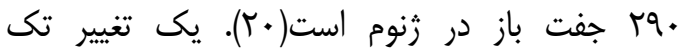

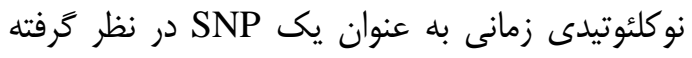

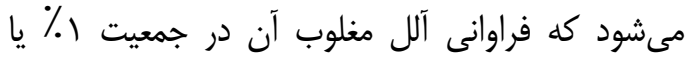

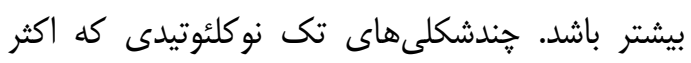
موارد حالت دو آللى دارند مزاياى شناخته شده و قابل

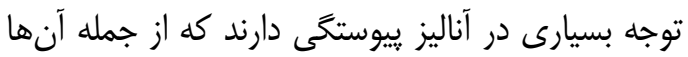

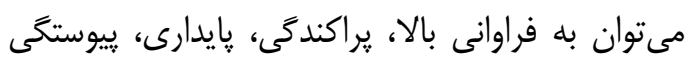

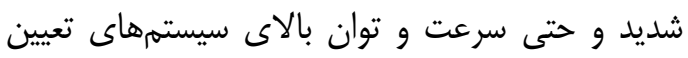

SNP

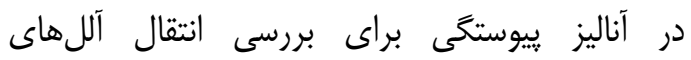

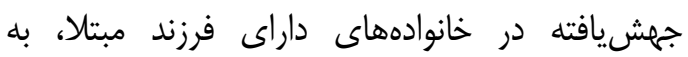

بيمارى تاى ساكس (TSD) يك بيمارى زنتيكى با

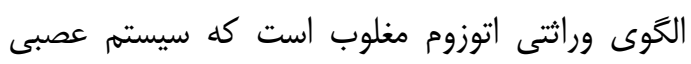

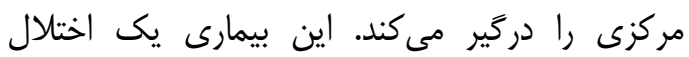
ذخيره ليزوزومى است كه علت آن نقص در عملكرد

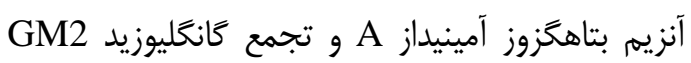
در ليزوزوم است (اوr). شدت بيمارى بسته بيه اينكه جه مقدار از فعاليت آنزيم باقى مانده متفاوت است و و إن

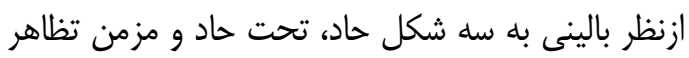

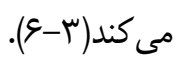
بتا هخَزوزآمينيداز A يك آنزيم هترودايمر است كه از يك زير واحد ه و يكى زير واحد م تشكيل شده است زير واحد م توسط زن HEXA واقع در كروموزوم ها و و

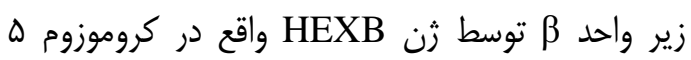

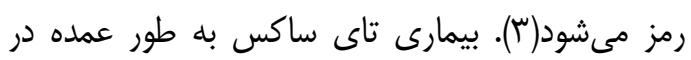

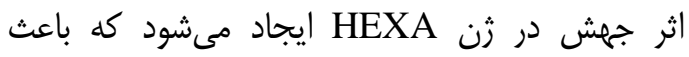
نقص در زير واحد لم و در نتيجه ناكارايى آنزيم HexA

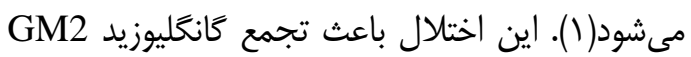

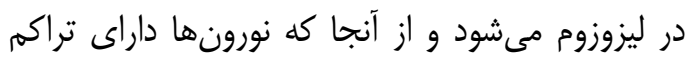

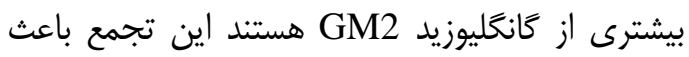

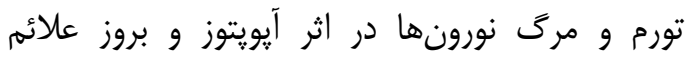

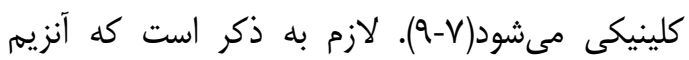
GM2 براى تجزيه سوبستراى خود به به لهایه activator اين كوفاكتور با اتصال به كَانعَليوزيد GM2 و ايجاد كميلكس محلول در آب شرايط را براى تجزيه دانيو در محيط آبدوست ليزوزوم فراهم مى كند، جهش در در ثرن

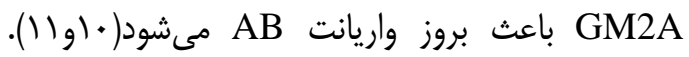
تشخيص بيماران مشكوك به تاى ساكس از طرويق

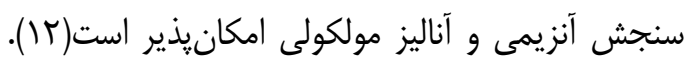

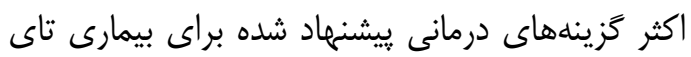

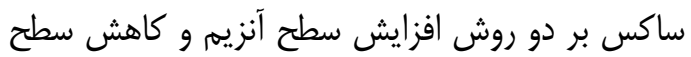

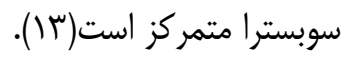
تاى ساكس از بيمارىهاى زنتيكى نادر است شيوع

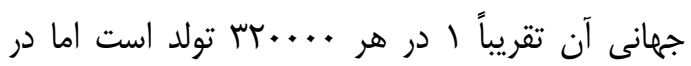

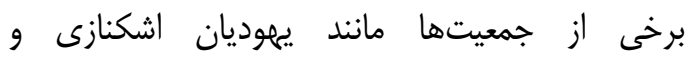

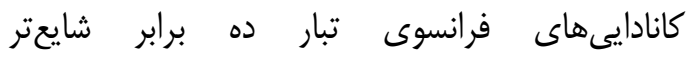

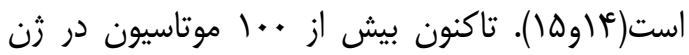


موقعيت •

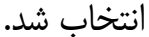

در اين تحقيق از روش Tetra-Primer ARMS براى تعيين زنوتيِ ماركر استفاده شد. اين روش به دو يرايمر خارجى و دو يرايمر داخلى و اختصاصى

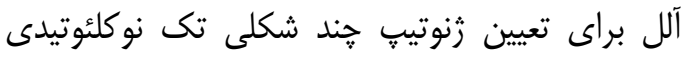

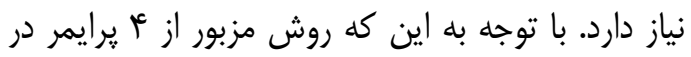
يك واكنش بهره مى گيرد، بنابراين مىتوان هر دو دو آلل ماركر را به طور همزمان بررسى كرد (Tها يرايمرهاى مورد استفاده در اين مطالعه از طريق پاييخاه اينترنتى Tetra primer ARMS PCR Search Frame استفاده از نرمافزار Oligo7 طراحى شدند (צr). توالى يرايمرها در جدول انشان داده شده است. محلول واكنش PCR در حجم نهايى هr ميكروليتر به صورت زير تهيه شد: هرLL/• از دو يرايمر خارجى ، (1+Pm) (1.Pm) ، $(\Delta \mathrm{U} / \mu \mathrm{L})$ Taq DNA Polymerase $; \cdot / r \omega \mu \mathrm{L}$ ز $r / \Delta \mu \mathrm{L}$ ، (1·mM) dNTP mix زl $1 \mu \mathrm{L}$ $\mathrm{MgCl}_{2}$ ز $\quad l \mu \mathrm{L} \quad(\Delta \cdot \mathrm{mM})$ TaqDNAbuffer كه در نهايت با $(\Lambda \cdot n g)$ DNA r $\mu \mathrm{L},(\Delta \cdot \mathrm{mM})$ dd به حجم roj $\mathrm{ddH}_{2} \mathrm{O}$ PCR بر روى نمونههاى DNA زنومى توسط دستخاه

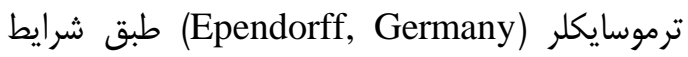
بهينه شده زير انجام شد: ه دقيقه دماى واسرشت اوليه

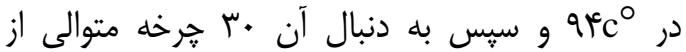

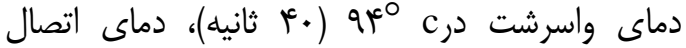

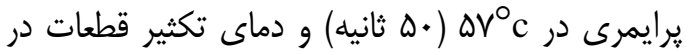

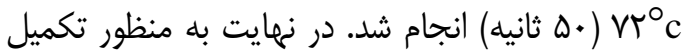
فرايند تكثير قطعات دماى

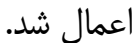
محصولات تكثير شده بر روى زل آكارز r ٪ به مدت

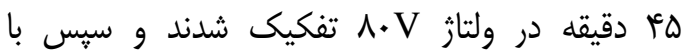

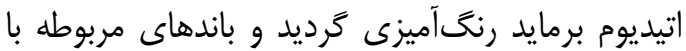
Gel documentation استفاده از دستخاه (نور Uود بررسى قرار گرفتند. (Biometra)

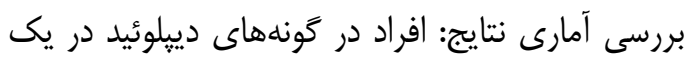
لوكوس هموزيخوت يا هتروزيخوت هستند. وجود الماري هتروزيخوسيتى نشاندهنده وجود تنوع زنتيكى است. تخمين فراوانى أللى ، فراوانى زنوتييى فنوتيڤ هاى
ماركرهاى اطلاع دهنده (كويا) نياز است. يكى از ويزگى هاى مهم يك ماركر اطلاع دهنده اين است كه

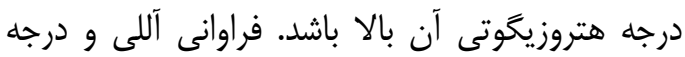

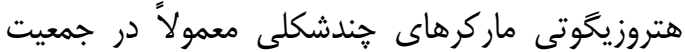
هاى مختلف متفاوت است. بنابراين در مطالعات ييوستخى براى شناسايى افراد ناقل (هتروزيخوت) و تشخيص ييش از تولد به روش غيرمستقيه، ماركرهاى

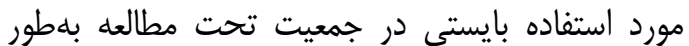
جداگًانه بررسى شوند. تاكنون هيج مطالعهاى مبنى بر بررسى ماركى بردهاى

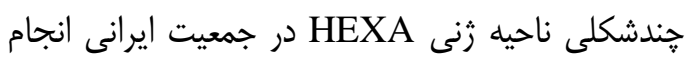

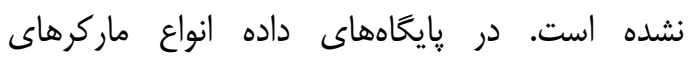
קندشكلى براى ناحيه زنى HEXA معرفى شده است. از بين ماركرهاى جندشكلى موجود، rs2288258 در

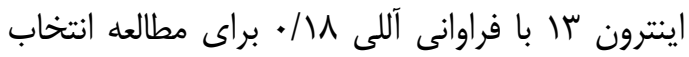
شد. در اين مطالعه خصوصيات زنوتيبى و اطلاع دهندگى اين ماركر در جمعيت اصفهان به عنوان نمونه اى از جمعيت ايران مورد بررسى قرار گرفته است كه

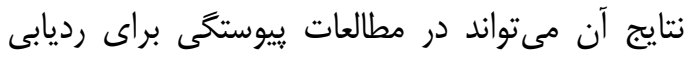
جهش به زن HEXA و همجنين تقويت اطلاعات ساختارى زنتيكى جمعيت ايران مورد استفاده قرار گيرد.

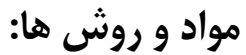
نمونهيَى و استخراج DNA: در اين مطالعه نمونه هاى خون از ئا فرد سالم و غير خويشاوند در جمعيت

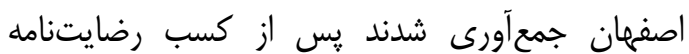

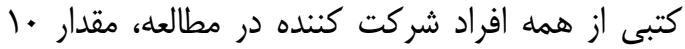
ميلىليتر از خون محيطى اين افراد براى استخراج

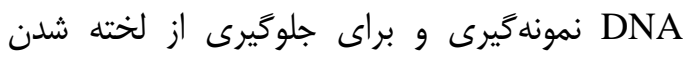
خون در لوله حاوى يك ميلىليتر EDTA با غلظت

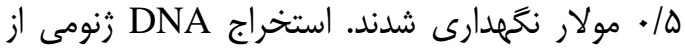
سلولهاى خون افراد به روش غير آنزيمى ميلر انجام شد و سيس كميت و كيفيت آن آن توسط دستخاه اسيكتروفتومتر مورد بررسى قرار

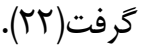
ماركر و تعيين زنوتيڤ: كليه ماركرهاى SNP موجود در

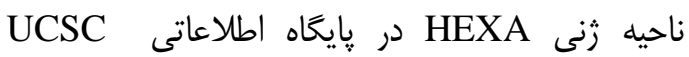
dbSNP Genome browser كرفتند (ساؤآ) و در نهايت ماركر rs2288258 در 
قرار گرفت. اين ماركر يك جند شكلى تك نوكلئوتيدى

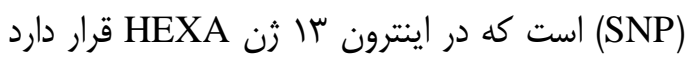
و داراى آلل غالب A و آلل مغلوب GA مى رنوتيّ هاى AA، و AG و شناسايى مىباشند. نمونههاى DNA افراد سالم و غير خويشاوند با استفاده از يرايمرهاى اختصاصى و روش Tetra-primer ARMS PCR

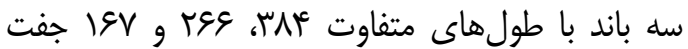

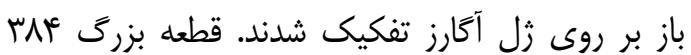

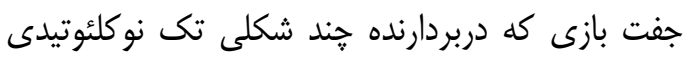
است نشان دهنده باند كنترل است و دو قطعه كوجى ع و و ا IV جفت بازى هر يك به ترتيب نشان دهنده

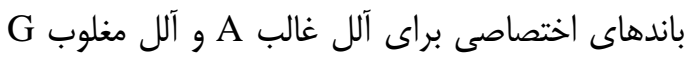

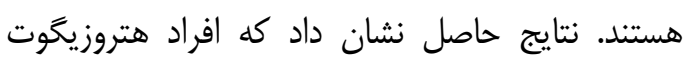
داراى هر سه باند در موقعيتهاى عاى

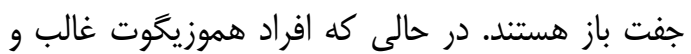
مغلوب تنها داراى باند كنترل و يكى از دالن دو باند اختصاصى آلل بودند (شكل ( ).
هموزيخوت و هتروزيخوت و وجود تعادل هاردى واينبرى (HWE) با استفاده از نرمافزار Marker مى كند كه در جمعيتى با جفتگيرى تصادفى بدون انتخاب، جهش، يا مهاجرت فراوانىهاى آللى و فراوانى تمكئى هاى زنوتيبى از نسلى به نسل ديخر ثابت هستند(

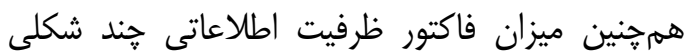
Power Marker نيز با استفاده از نرم افزارك (PIC) انجام شد. فاكتور PIC معيارى براى تعيين ميزان

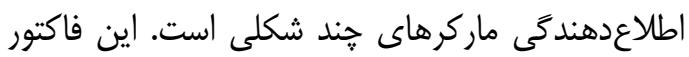
براى ماركرهايى كه داراى تعادل هاردى-واينبرى درى در جمعيت مىباشند تعريف مىشود كه به تعداد و فراوانى آللها و درجه هتروزيخوسيتى مشاهده شده در جمعيت وابسته است (rq).

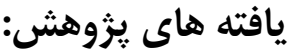
ماركر زنتيكى rs2288258 در ناحيه زنى HEXA در يك گروه از افراد سالم در جمعيت اصفهان مورد بررسى

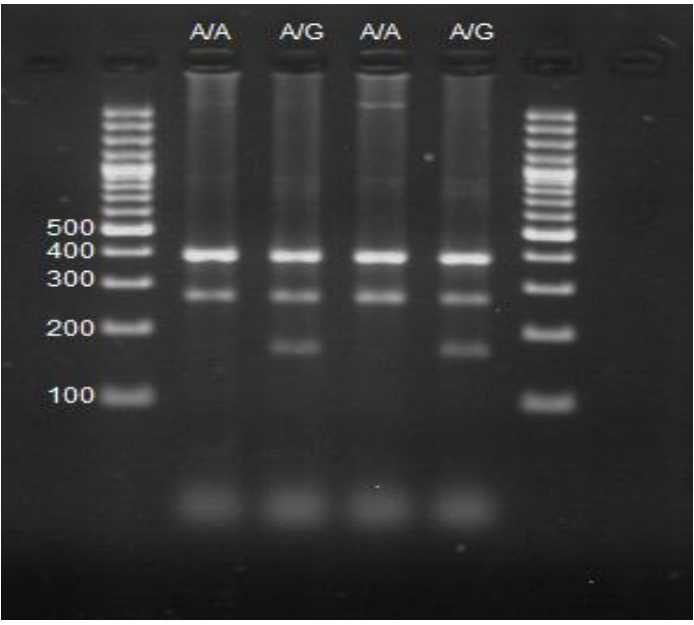

شكل (-تعيين زنوتيب ماركر rs2288258 با استفاده از روش Tetra-primer ARMS PCR.

مربوط به فرد هتروزيخوت A/G مىباشد. نمونهها بر روى زل آكارز \% r تفكيك شده اند.

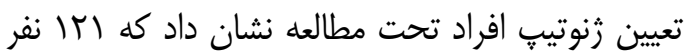

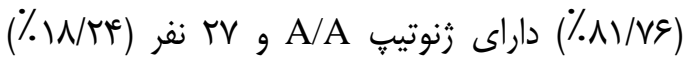
داراى زنوتيت A/G بودند. فراوانى مربوط به اين

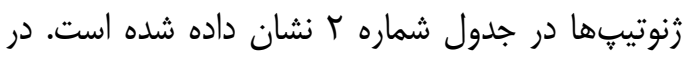
جمعيت مورد مطالعه فراوانى آللى آللهاى غالب آلب وادهاه

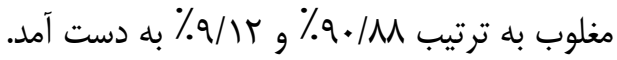

براى هر فرد يك ستون در نظر گرفته شده است. در

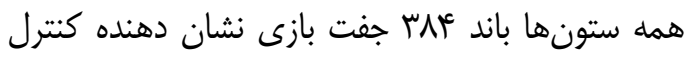
داخلى است. باندهاى اختصاصى وعت و و 19V جفت

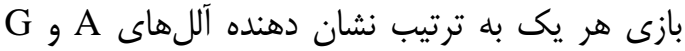

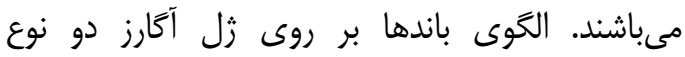

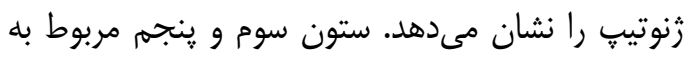
يك فرد هوموزيغوت A/A وستون جهمارم وششم 
جدول ا - توالى برايمرهاى طراحى شده براى تعيين آللهاى ماركر rs2288258 توسط روش Tetra-primer ARMS PCR

Forward inner primer (A allele) Reverse inner primer ( $\mathrm{G}$ allele)

Forward outer primer

Reverse outer primer
5'- GCTGCCTTTCAGACATCCATATA -3'

5'- CCAAATAACTCAATCCCTTTAGAAGAC -3'

5'- CAAGGACAGGATTTCGCATC -3'

5'- AGTCTCTCCTTCCCCATTTCG -3'
آزمون دقيق فيشر نشان داد كه مقدار P براى جمعيت

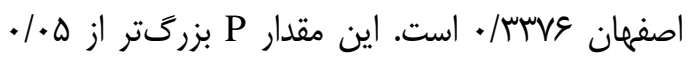
است كه بيانگر وجود تعادل هاردى واينبرگ براى اين معان ماركر در جمعيت اصفهان است (جدول شماره ؟).
وجود تعادل هاردى واينبرى از طريق محاسبه P بر إن

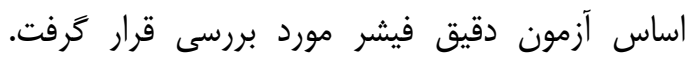

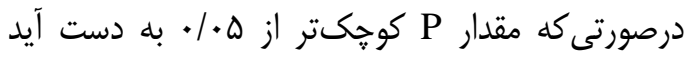

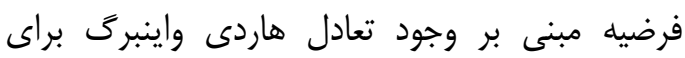

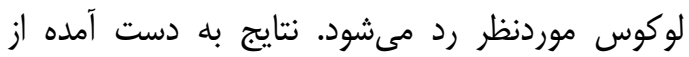

جدول r- تعداد افراد و فراوانىهاى مشاهده شده براى انواع زنوتيبهاى ماركر rs2288258 در جمعيت اصفهان.

\begin{tabular}{|c|c|}
\hline $\mathrm{A} / \mathrm{G}$ & $\mathrm{A} / \mathrm{A}$ \\
\hline TV & $|r|$ \\
\hline - /MAYE & . /AIVG \\
\hline
\end{tabular}

است (•r). نتايج به دست آمده از مطالعه حاضر نشان داد كه مقدار PIC براى ماركر rs2288258 در جمعيت ناضن

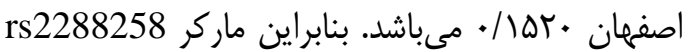
مىتواند به عنوان يك ماركر در مطالعات ييوستخى در جمعيت اصفهان معرفى شود(جدول شماره ب).
بررسىها نشان مىدهد كه PIC بزركتر از ما /

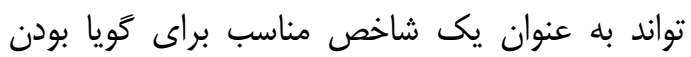

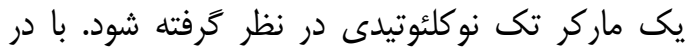

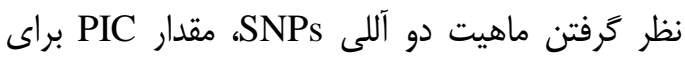
اين نوع ماركرهاى در مقايسه با ريز ماهوارهها كمتر

جدول بـ- مقايسه فراوانى آللى ماركر rs2288258 در نمونهاى از جمعيت ايران (جمعيت اصفهان) با جمعيتهاى ديكر

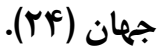

\begin{tabular}{|c|c|}
\hline $\begin{array}{c}\text { rs2288258 } \\
\text { G آلل }\end{array}$ & جمعيت \\
\hline rT,Q & آفريقا \\
\hline$f, \varphi^{c}$ & ارويا ا ل \\
\hline$f, q$ & ايتاليا \\
\hline$q, 1 r$ & ايران (مطالعه حاضر) \\
\hline$\varphi, \Delta$ & تخززاس \\
\hline$\Lambda \Lambda, r$ & جين \\
\hline $\mid v, 1$ & جين تاييه \\
\hline ro & زإين \\
\hline$i \Delta, q$ & كنيا لوهيا \\
\hline rq,q & كنيا ماسايى \\
\hline IV,Y & مكزيى \\
\hline$r \vee \wedge$ & نيجريه \\
\hline$r F, 1$ & ميانغَين \\
\hline
\end{tabular}


مقايسه نتايج به دست آمده از اين مطالعه با اطلاعات

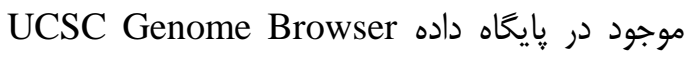
نشان مىدهد كه فراوانى آلل دراى ماركر rs2288258 در نمونهاى از جمعيت ايران (جمعيت اصفهان) نسبت به جمعيتهاى نيجريه ، زاين ، هين،

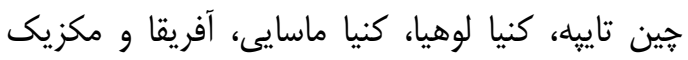
كمتر است در حالى كه از جمعيتهاى ارويا، تخزاس و ايتاليا بيشتر است. اين يافتهها نشان مىدهد كه ماركر rs2288258 مىتواند در جمعيتهاى نيجريه، كنيا

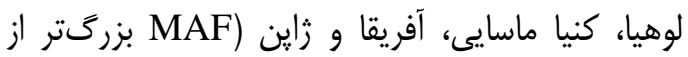

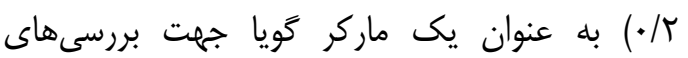

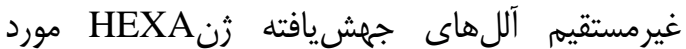

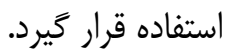
مشخص شده است كه انحراف از تعادل هاردى واينبرى مىتواند صحت بررسىهاى آمارى را تحت تأثير قرار دهد. ازاينرو یِ از تعيين فراوانى آللى و زنوتييى افراد، در مرحله بعد، وجود تعادل هاردى واينبرى مورد بررسى قرار گرفت. نتايج حاصل نشان داد كه تعادل هاردى واينبرگ براى ماركر مارك

$$
\text { در جمعيت اصفهان وجود دارد. }
$$

در مجموع نتايج حاصل از اين مطالعه نشان داد كه

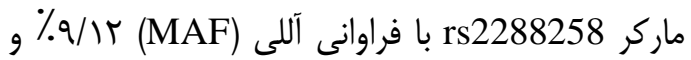

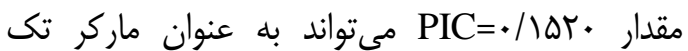
نوكلئوتيدى در آناليز ييوستخى و تشخيص مولكولى معالى غيرمستقيم آللهاى جهشيافته زن HEXA در

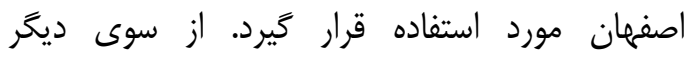

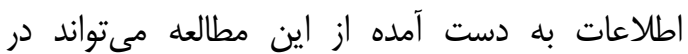
تقويت اطلاعات ساختارى زنتيكى جمعيت ايران مؤثر باشد.

\section{سباسگزارى}

از معاونت محترم يزوهشى دانشگاه اصفهان جهت تأمين بودجه اين مطالعه در غالب يروهانه و كليه افرادى كه در تهيه نمونه ما را يارى نمودهاند تشكر و قدردانى مى شود.
امروزه شناسايى صحيح ثن عامل بيمارى اصلىترين جالش در تشخيص مولكولى بيمارىهاى جندزنى منى

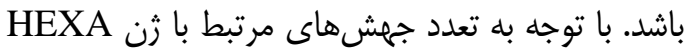
و يرهزينه و وقت گير بودن بررسى مستقيم جهشها، بررسى ماركرهاى جند شكلى در آناليز يبيوستخى

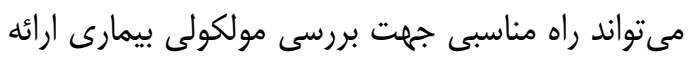

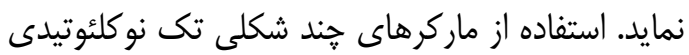
براى بررسىهاى غيرمستقيم به علت پايدارى (SNPs) و همجنين بيوستخى شديد با ثن بسيار قابل اعتمادتر

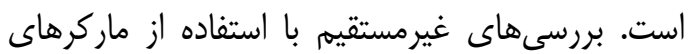
קند شكلى موجود در زن HEXA مىتواند در تعيين افراد ناقل (هتروزيخوت) و تشخيص ييش از تولد در خانوادههاى مبتلا به TSD وابسته به HEXA مورد استفاده قرار گيرد. از بين ماركرهاى موجود در ناحيه زنى HEXA، ماركر rs2288258 در اينترون سا ثا ثن دين براى اين مطالعه انتخاب شد. در اين مطالعه فراوانى

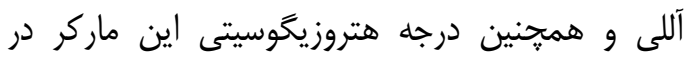

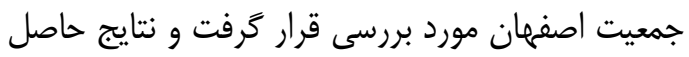
با اطلاعات مربوط به ديخر جمعيتها مقايسه شد. نتايج به دست آمده از مطالعه حاضر بر روى ماركر

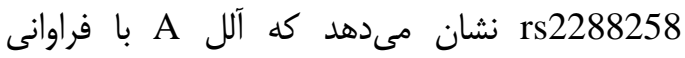

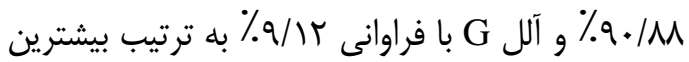
و كمترين فراوانى را در جمعيت اصفهان دارند. فراوانى آللى و هم جنين درجه هتروزيخوسيتى براى

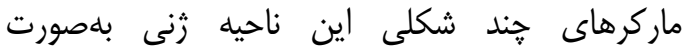
اختصاصى براى جمعيتهاى مختلف توسط بايخاه داده UCSC Genome Browser نتايج در جدول شماره س نشان داده شده است. بر اساس

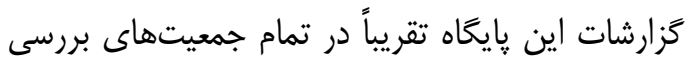
شده آلل A با فراوانى بيشتر بلهنوان آلل غالب و و آلل G آلل مغلوب شناخته شده است؛ هم جنين مشخص

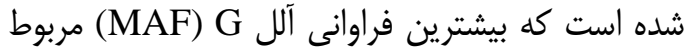
به جمعيت كنيا لوهيا مىباشد. اين در حالى است كه جمعيت ارويا در مقايسه با ساير جمعيتها داراى فراوانى

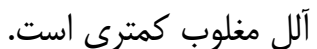




\section{References}

1. Kolter T, Schepers U, Sandhoff K. Taysachs disease encyclopedia of molecular mechanisms of disease. Springer Publication.2009; P.2027.

2. Parenti G, Pignata C, Vajro P, Salerno M. New strategies for the treatment of lysosomal storage diseases. Int $\mathrm{J}$ Mole Med2013;31:11-20.

3. Myerowitz R. Tay-sachs disease causing mutations and neutral polymorphisms in the Hex A gene. Hum Mut1997:195-208.

4. Maegawa GH, Stockley T, Tropak M, Banwell B, Blaser S, Kok F, et al. The natural history of juvenile or subacute GM2 gangliosidosis 21 new cases and literature review of 134 previously reported. Pediatrics 2006;118:1550-62.

5. Jamrozik Z, Lugowska A, Golębiowski M, Krolicki L, Mączewska J, Kuzmakozakiewicz M. Late onset GM2 gangliosidosis mimicking spinal muscular atrophy. Gene 2013; 527:679-82.

6. Bley AE, Giannikopoulos OA, Hayden

D, Kubilus K, Tifft CJ, Eichler FS. Natural history of infantile GM2 gangliosidosis. Pediatrics 2011; 128:1233-41.

7. Huang JQ, Trasler JM, Igdoura S, Michaud J, Hanai N, Gravel RA. Apoptotic cell death in mouse models of GM2 gangliosidosis and observations on human Tay-sachs and Sandhoff diseases. Hum Mole Genet1997;6:1879-85.

8. Mullen T, Obeid L. Ceramide and apoptosis exploring the enigmatic connections between sphingolipid metabolism and programmed cell death. Anticancer Agents Med Chem2012; 12:340-63.

9. Myerowitz R, Lawson D, Mizukami H, Mi Y, Tifft CJ, Proia RL. Molecular pathophysiology in Tay-sachs and Sandhoff diseases as revealed by gene expression profiling. Hum Mole Genet 2002; 11:1343-51. 10.Platt FM. Sphingolipid lysosomal storage disorders. Nature 2014; 510:68-75.

11. Sandhoff K, Harzer K. Gangliosides and gangliosidoses principles of molecular and metabolic pathogenesis. J Neurosci2013;33:10195-208.

12. Karimzadeh P, Jafari N, Biglari HN, Dari SJ, Abadi FA, Alaee MR, et al. GM2gangliosidosis Sandhoff and Tay-sachs disease diagnosis and neuroimaging findings an Iranian pediatric case series. Iranian J Child Neurol 2014; 8:55.
13. Tandon A. Therapeutic options for Taysachs Disease. J Biol Med 2002;19:10-2.

14. Triggsraine B, Akerman B, Clarke J, Gravel R. Sequence of DNA flanking the exons of the HEXA gene and identification of mutations in Tay-sachs disease. Am J Hum Genet1991; 49:1041.

15. Stenson PD, Ball EV, Howells K, Phillips AD, Mort M, Cooper DN. The human gene mutation database providing a comprehensive central mutation database for molecular diagnostics and personalised genomics. Hum Genom2009;4:69.

16. Frisch A, Colombo R, Michaelovsky E, Karpati M, Goldman B, Peleg L. Origin and spread of the 1278insTATC mutation causing Tay-sachs disease in Ashkenazi Jews genetic drift as a robust and parsimonious hypothesis. J Hum Genet 2004;114:366-76.

17.Haghighi A, Rezazadeh J, Shadmehri AA, Haghighi A, Kornreich R, Desnick RJ. Identification of two HEXA mutations causing infantile onset Tay-sachs disease in the Persian population. J Hum Genet 2011;56:682-4.

18. Martin DC, Mark BL, Triggsraine BL, Natowicz MR. Evaluation of the risk for Tay-sachs disease in individuals of French Canadian ancestry living in new England. Clin Chem2007; 53:392-8.

19.Karpati M, Gazit E, Goldman B, Frisch A, Colombo R, Peleg L. Specific mutations in the HEXA gene among Iraqi Jewish Taysachs disease carriers dating of founder ancestor. Neurogenetics 2004; 5:35-40.

20.Kruglyak L, Nickerson DA. Variation is the spice of life. Nature Gene2001; 27:2345.

21.Botstein D, Risch N. Discovering genotypes underlying human phenotypes past successes for mendelian disease future approaches for complex disease. Nature Genet 2003; 33:228-37.

22.Miller S, Dykes D, Polesky H. A simple salting out procedure for extracting DNA from human nucleated cells. Nucle Acids Res 1988; 16:1215.

23. Adrienne Kitts, MS, Lon Phan, Minghong W, Johnbradley H. The database of short genetic variation dbSNP. $2^{\text {th }}$ ed. NCBI Handbook2013.

24. UCSC Genome Browser. NCBI Handbook. $2^{\text {th }}$ ed. 2013. 
25.Ye S, Dhillon S, Ke X, Collins AR, Day IN. An efficient procedure for genotyping single nucleotide polymorphisms. Nucleic Acids Res 2001;29: 88.

26. Old J, Harteveld CL, TraegerSynodinos J, et al. Prevention of thalassaemias and other haemoglobin disorders. $2^{\text {th }}$.ed Laboratory protocols Publication.2012.

27.PowerMarker software. Available from: www.statgen.ncsu.edu/powermarker/

28. Guo SW, Thompson EA. Performing the exact test of Hardy-Weinberg proportion for multiple alleles. Biometrics 1992:361-72.

29.Elahi E, Kumm J, Ronaghi M. Global genetic analysis. $J$ Biochem Mole Biol2004;37:11-27.

30.Chen H, He H, Zou Y, Chen W, Yu R, Liu $\mathrm{X}$, et al. Development and application of a set of breeder-friendly SNP markers for genetic analyses and molecular breeding of rice Oryza sativa L. Theor Appl Genet 2011; 123:869-879. 


\title{
Allele Frequency and Genotyping of rs2288258 Polymorphism in HEXA Gene Region in the Isfahan Population
}

\author{
Vahhab $N^{l}$, Jazaeri $A^{l}$, Vallianborujeni $S^{l^{*}}$
}

\section{Abstract}

(Received: May 4, 2016

Introduction: Tay-Sachs is a genetic disorder with autosomal recessive inheritance affecting the central nervous system. The disorder mainly results from mutations in the HEXA gene on chromosome 15. Sequencing is used to detect mutations and sequence variations in the HEXA gene, which is expensive and time consuming. Alternatively, linkage analysis of polymorphic markers such as single nucleotide polymorphism (SNP) could be used in heterozygous carrier detection and prenatal diagnosis of the disease in families with an affected individual.

Materials \& methods: A large number of SNP markers have been introduced for the HEXA gene in the electronic databases. In the present study the genotype and informative situation of rs2288258 genetic marker in HEXA gene region was investigated using Tetra-primer ARMS PCR technique with newly designed primers in Isfahan population. Estimation of allelic frequency, genotype frequency, presence of Hardy Weinberg Equilibrium (HWE) and the amount of polymorphism information content (PIC) was computed by Power Marker software.

Findings: The results indicated $9.12 \%$ minor allele frequency (MAF) and $\mathrm{PIC}=0.1520$ for rs2288258 marker in the Isfahan population. Also, analysis of Hardy-Weinberg Equilibrium showed the presence of equilibrium for this marker in the mentioned population.

Discussion \& conclusions: The results indicated $9.12 \%$ minor allele frequency (MAF) and $\mathrm{PIC}=0.1520$ for $\mathrm{rs} 2288258$ marker in the Isfahan population. Also, analysis of Hardy-Weinberg Equilibrium showed the presence of equilibrium for this marker in the mentioned population. Totally, according to the results of this study rs2288258 genetic marker could be introduced as an SNP marker for linkage analysis in carrier detection and prenatal diagnosis of HEXA mutations in Isfahan population.

Keywords: HEXA, Linkage analysis, Single nucleotide polymorphism, Isfahan population 